\title{
DISUSED AREAS AND URBAN REGENERATION. THE HISTORIC CENTRE OF VICENZA, ITALY
}

\author{
Enrico PIETROGRANDE ${ }^{a}$, Alessandro DALLA CANEVA ${ }^{b}$, Ignasi NAVÀS SALVADÓc \\ ${ }^{a, b}$ Department of Civil, Environmental, Architectural Engineering, University of Padua, \\ via Marzolo 9, 35131, Padua, Italy \\ ${ }^{c}$ Architectural Researcher, Barcelona, Spain \\ E-mails: ${ }^{a}$ enrico.pietrogrande@unipd.it (corresponding author); \\ balessandro.dallacaneva@dicea.unipd.it; cignasi.navas@gmail.com
}

Received 15 December 2016; accepted 09 January 2017

\begin{abstract}
This work concerns Vicenza, a city located not far from Venice in the north-east corner of Italy, and it specifically refers to an area situated on the outskirts of the city's urban fabric between the perimeter of its ancient walls and the banks of the Bacchiglione river, in the shadow of the abandoned monastery of St. Biagio.

The idea of restoring that physically and socially degraded area of the city of Vicenza has long been the object of discussion on the part of local authorities. Once intimately linked to the city's historic center, the area gradually lost its functional and social identity becoming first a parking lot and then equipped as a city warehouse.

The intent to regenerate the area and the observation that the relationship between the city and its river is constantly refused, or delayed, lead to recognize in the long edge of the area a unique meeting opportunity which allows to repair the water-city association, recuperating rituals and connections from the past. The municipality is presently planning on pursuing a qualitative restoration of the area which will be used for social and cultural enrichment.

The final part of the current work outlines some proposals that were developed during the Architectural and Urban Composition 2 course recently offered by the Department of Civil, Environmental and Architectural Engineering of the University of Padua (Italy).
\end{abstract}

Keywords: Vicenza urban centre, Bacchiglione river, urban regeneration, memory, urban identity, public space.

\section{Introduction}

Urban morphological and typological studies are fundamental elements in the current work. These studies have assumed a particularly important position in the Italian architectural culture from the mid- $20^{\text {th }}$ century. In opposition to achievements attained by the modern movement, they propose a new approach, according to which history and its formal contents are deeply investigated and become a basic part of the project so that the new can take shape only in connection with the past and as a continuation of it. A way of seeing a project in which the real man rather than an ideal one is considered gradually flanks the view that the modern movement held of the past, that is the Le Corbusier's vision of a new man projected onto a hypothetical future. Architectural regeneration takes place thus only through the past, without mimicry, in the light of present-day needs. This is a form of tradition- alism that, keeping a sense of proportion, makes it possible "to take from the past that which moves us today and to take from the present that which is most alive rejecting aberrations outside of life" (Samonà 1929). Scholars of urban morphology propose to investigate history to rediscover the reasons underlying a project, fully aware that it is not the task of architecture to impose new life solutions but rather to make its legacy and revelations available to everyone: "History should be investigated and reproposed as a rethinking that continually excavates where work has already been done to rediscover new aspects and «new» things" (Polesello 2002).

From this perspective, the object of the planning experience is the city, and architecture becomes the defining element of the city itself. The project is considered as an "analogous city" made up of fragments, rediscovered architectures, and known forms assembled in 
an original way that is nonetheless capable of evoking meanings and constructing infinite urban relations. The analogy means recalling, through the analogic process and thus of invention, a lost world, which is the world of the city and its types.

The method is rooted in the well-known School of Venice and "is based upon the conceptual operation of reducing traditional urban types into meaningful fragments in order to recompose them bearing in mind the following factors: the sense of forms settled with the passage of time, their specificity as well as their hybridizations or contaminations with precedent types; and their reification in a new context" (Delledonne 2005). The design invention then composes already known forms. It is the result of a dialectical relationship with history that may help to uncover new aspects and new things.

The idea that the transformation and the protection of the urban landscape can occur according to a unitary process is the basis of the teaching experience described below. The assumption is in line with the main contribution of the Italian culture during the second half of the twentieth century. According to the School of Venice, the relationship between a city and architecture, referring to the city's scale in the study of architecture, is the fundamental fact that is at the origin of an effective theory on the project, which defines a synthesis between analysis and design, architecture and urban planning. Giuseppe Samonà, founder of the school, turned his attention to the "history of the architectural object, analysed and reconstructed using both ex cathedra lectures and exercises" (Domenichini 2011), expressing an interest in the pragmatism of history in terms of doing things.

Egle Renata Trincanato accompanied students on site in Venice to investigate the buildings, explaining the reasons for "they had patently to be in that place and at time", and studying with students the building themselves to determine the means for future designs. Saverio Muratori's teaching was rooted in the history too. He wrote that students must first learn that the study of a building begins with understanding its environment. Aldo Rossi, Muratori's assistant in Venice, insisted on the absolute correspondence between the analysis of building and urban analysis, emphasizing the importance of finding precise relationship between architectural and urban structures. His fundamental 1960s studies about typological analysis were published in 1966 in the book L'architettura della città (The Architecture of the City) (Rossi 1966), in which the spatial aspects and formal image of the transformations in the city are studied as a premise on which to base the design of the new architecture.
At the Institute of Architecture in Venice, with the passing of the years and teachers, the analytical study of architecture consolidates interest in the city, starting with the examination of its urban fabric. The same reference to pre-existing environmental and historical artefacts is believed as a founding value of teaching by the authors of this article, especially in the present day, marked by key issues of sustainability, and underpins the teaching experience described in the following pages.

Monestiroli says on the subject: "As we can see from history, it is not forms that are transported, but the ideas and the emotions evoked by those forms. It is only by recognizing those ideas and the experience of those emotions that we will be able to find new forms capable of representing the values of our time" (Monestiroli 2010). Quality architectural planning also means being able to hand down to those who come after us the memory we inherited. In this respect, projects uncovering architectural typologies find newly a civic tradition that permits a community to recognize in buildings and places the civic values of its being part of the world.

The project experience enters into the heart of a city and its forms addressing unresolved fragments and rediscovering continuity without nostalgia with urban forms. As Anthony Vidler pointed out "this attitude belongs to those who have dedicated their design ability to study the avenue, the colonnade, the street, the square, the park, the house, institutional places, equipment under the terms of a continuous typology of elements. These ones keep together, united as they are to one another, the ancient urban fabric with new institutions so that a new experience of the city can be constructed" (Vidler 2005).

\section{Characteristics of cities of the Veneto Region}

This study focuses, from an applicative point of view, on the historic fabric of the center of Vicenza (Fig. 1), a city situated between Venice and Verona in the Northern corner of the Italian Peninsula, and it is in particular concerned with an area bathed by the Bacchiglione river near to where the desecrated church of St. Biagio stands. With Padua and Treviso, Vicenza was one of the most important cities of the Serenissima Republic of Venice, the maritime republic that boasted Venice as its capital. With other less important, smaller cities, it was part of a network extending into the region's countryside and including urban centers enclosed behind walls and in the shadow of castles busting with history and art. The architect Aldo Rossi dedicated his essay Caratteri Urbani Delle Città Venete (Urban Characteristics of Cities of the Veneto) to ex- 
amining the urban characteristics of the small cities of the Republic of Venice, the Italian state whose capital, Venice, has most characterized "its own institutions and its own political and cultural autonomy" and has maintained its indipendence up until the modern era (Rossi 1970).

Like the other cities of the Veneto Region, Vicenza has conserved largely intact its walls, which allow the reading of its urban form as it changed over time. The walls constitute, in fact, the real architecture of a city conceived as a collective building. It should also be remembered that the walled cities of the Veneto Region, in this case Vicenza, possess neither center nor peripheral area and present at the end of the Middle Ages definite morphological characteristics which are transmitted to the Renaissance. The fabric of the city at the threshold of the fifteenth century admits few, rare variations: "with its palazzi (urban mansions), houses, churches and public facilities - theaters, hospitals, academies the urban countenance of Vicenza presents particular monumental architectures in an already formed fabric" (Crippa 1964). In fact, already in the second half of the thirteenth century, Vicenza established precise rules and modalities on how volumes could be composed. "In 1264 the assembly of the citizens approved the prohibition of tearing down existing buildings and of constructing new structures more then fifteen meters tall. Furthermore, it was required to respect the regulations concerning alignments and care of the city's urban décor" (Rossi 1970).

During the Renaissance one of the most important architecture designed by Palladio, the Basilica placed at the centre of the city, is characterized by "the coexistence of gothic masonry and white stone", a coexistence leading to a singular effect "that is typical of Venice and becomes almost symbolic in the Filarete's fragment on the Grand Canal" (Rossi 1970). In a particularly posit- ive way, Palladio inserts its architectures in the urban landscape of the cites of the Republic of Venice.

At a later time, these matters have been studied by the authors of two volumes published in the 1980's containing graduate theses developed at the University of Architecture of Venice focusing on architectural and urban projects in cities of the Veneto Region. In the first one, entitled Progetti per la Città Veneta 1926-1981 (Projects for the city of the Veneto Region 1926-1981), Luciano Semerani discusses a "certain type of problem" that continues to be analyzed: the façade, the square, the park. "We continue to study certain subjects (the window, the architectural orders, the labyrinth). The history of the subject and the history of that type of problem come to constitute a path within the woods of the discipline, within the woods of the history of the architectures and of the city" (Semerani 1982). Interest in the characteristics of cities of the Veneto, and of Vicenza in particular, is the focus of the research and of the teaching concerning that area of Italy. The analysis of the city developed with designing aims, Semerani writes, conducts us back to "logical conventional passageways (the type, the parts of the urban structure, the rules) that lead design towards composition, prioritizing syntactic problems over grammatical ones, those of the building's eloquence and urban/collective image over its duration and correspondence to minimal standards of functionality".

In his introduction to the second volume entitled Progetti Veneziani (Venetian Designs), Gianni Braghieri observed that the design and planning concerning a city's historic center is "one of the most interesting subjects that is presently faced by architects". In the book "there are projects that regard the historic centre of the principal Lombard-Veneto cities such as Verona, Mantua, Vicenza, Padua, Treviso, Venice, to name just the most well-known ones", where, he underlines, "the

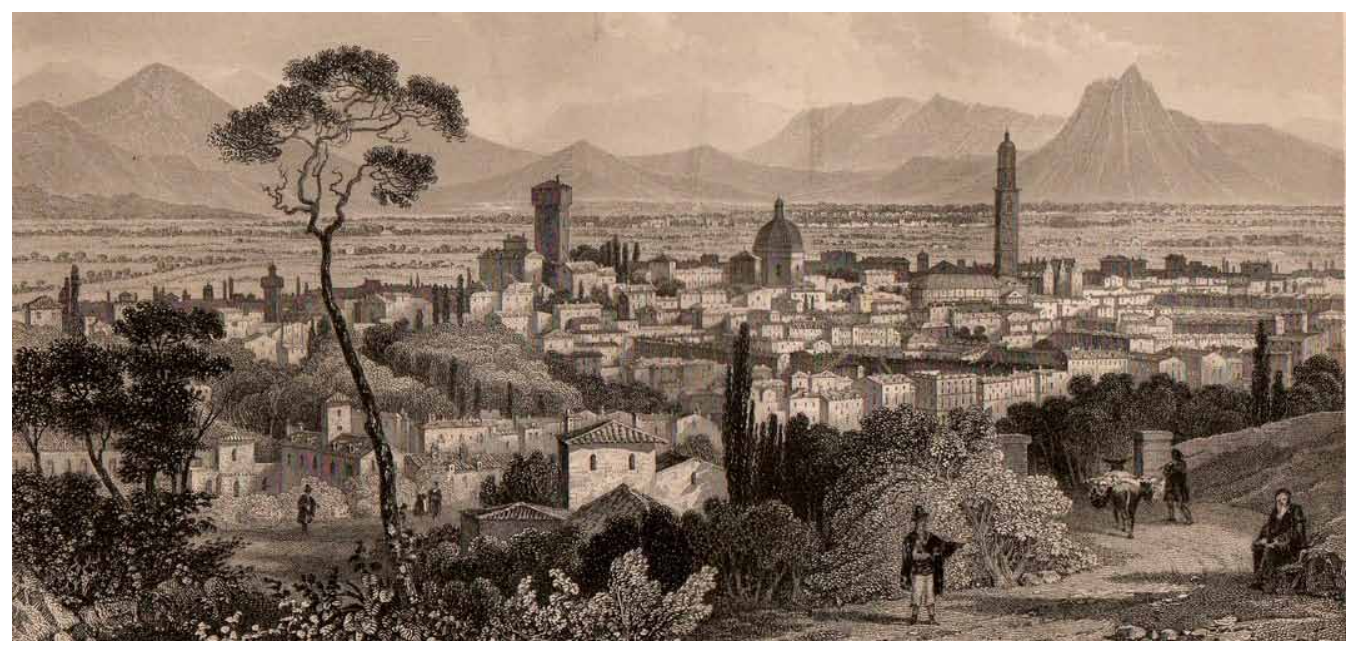

Fig. 1. View of Vicenza from the Berici Hills, work of the artist William Cooke Stafford in 1860 
rapport between historic and monumental buildings is always present" (Braghieri 1985). As an aside, the topic of the relationship between new architecture and historic city has recently been addressed through a design experience carried out in a didactic context and published in a small volume focusing on the historic center of Padua, a city only thirty kilometers away from Vicenza that can, in many respects, be considered its twin sister (Pietrogrande et al. 2014).

The popularity of Aldo Rossi's thought is confirmed in 1975 by observations made by a group of young architects who studied at the University of Architecture of Venice. One of these, Bruno Minardi, outlines in an article published in the Italian architectural journal Casabella the main features of his own approach: "Urban analysis and architectonic planning, building typologies and urban morphology, and history as a place where one can pick up affinities and analogies, are the constant points of reference for us". He reads the image of the city" as a place of architecture in which the street, avenue, square, cloister, and block constitute, in structural and subtly poetic terms, a field in which it is still possible and reasonable to operate" (Baldisseri et al. 1975).

\section{Notes on the relationship between historic center and design}

Continuing along these lines, other recent contributions are below outlined that focus on the subject of revitalizing urban areas that have lost contact with the urban fabric of historic significance they were once a part of. In an essay published in 1990, Carlo Martí Arís expresses what relationship architecture should have with the past. "Proposing a structural comprehension of phenomena stripped of its particular and contingent qualities, the typological approach opens the doors of the history to the action of analogic thought, converting it thus into a vast repertory of references which nourish the project. Since it is the solution of a specific problem, the design consists in the manipulation and transformation of this reference system that constitutes the basic material of architecture" (Martí Arís 1990).

Rafael Moneo in a study appeared in 1999 and republished in 2012 comments on his works in the following way. "My buildings were conceived, first of all, to respond in an appropriate way to the conditions of the urban fabric which they are a part of. All of these projects seek to be respectful of the place and intend to become a part of it". With regard to one of the most successful experiences of introducing a new building into an historic-artistic context, the extension of the Murcia City Hall in the Cardinal Belluga Square in
Murcia (Spain), Moneo explains that he interpreted the relationship with the context through "a fragmented system of pillars that are presented as a revisited version of the old Spanish retables, near the limit of the traditional sense of order" (Moneo 2012).

Adam Caruso in the brief text he dedicates to the Swiss architects Christian Kerez and Valerio Olgiati highlights "the traumatic effect that the arrival of Aldo Rossi as a visiting professor between 1972 and 1975 had on their formation as architects" at the Swiss Federal Institute of Technology (ETH) in Zurich. Caruso specifies that at our days Kerez and Olgiati, after the lesson of Rossi, "provide in their teaching an important and intense example to students of how to make work that has some significance in a world that no longer wants significant architecture" (Caruso 2009).

\section{Vicenza}

"The man who travels and does not know the city that is awaiting him, asks himself along the way how the mansion, the building, the mill, the theater, the marketplace will be. In every city of the empire, every building is different and disposed in a different way: but as soon as the stranger arrives in an unknown city and takes a look around at that combination of pagodas and dormers and haylofts in the meandering of canals, gardens, and rubbish dumps, he immediately distinguishes the palaces of the princes, the temples of the great priests, the inn, the prison, the slum. In that way, someone could say, the hypothesis is confirmed that every man brings in his mind a city formed only of differences, a city without figures and without form and the particular cities fill it in" (Calvino 1993).

Just as Italo Calvino points out, every city has its particular characteristics that define and form it; in the same way Vicenza has a specific urban form that determines it. It is in reference to these singular elements that the city can be explained. Natural elements and architecture are the components that determine the city, and the connection between them generates the urban form of Vicenza (Fig. 2a).

Throughout its long urban evolution, Vicenza has always been characterized by the incisive Bacchiglione river and its tributary Retrone which, together with the walls of the city, limit and define the historic center. In some areas these rivers, together with the old perimeter of the walls, act as a protective barrier for the historic center, but in other areas the rivers crisscross the city generating several picturesque bridges which become the gates of the historic center. As, for example, the bridge of the Angels that crosses the Bacchiglione river and that unites the eastern zone and the central part of the 


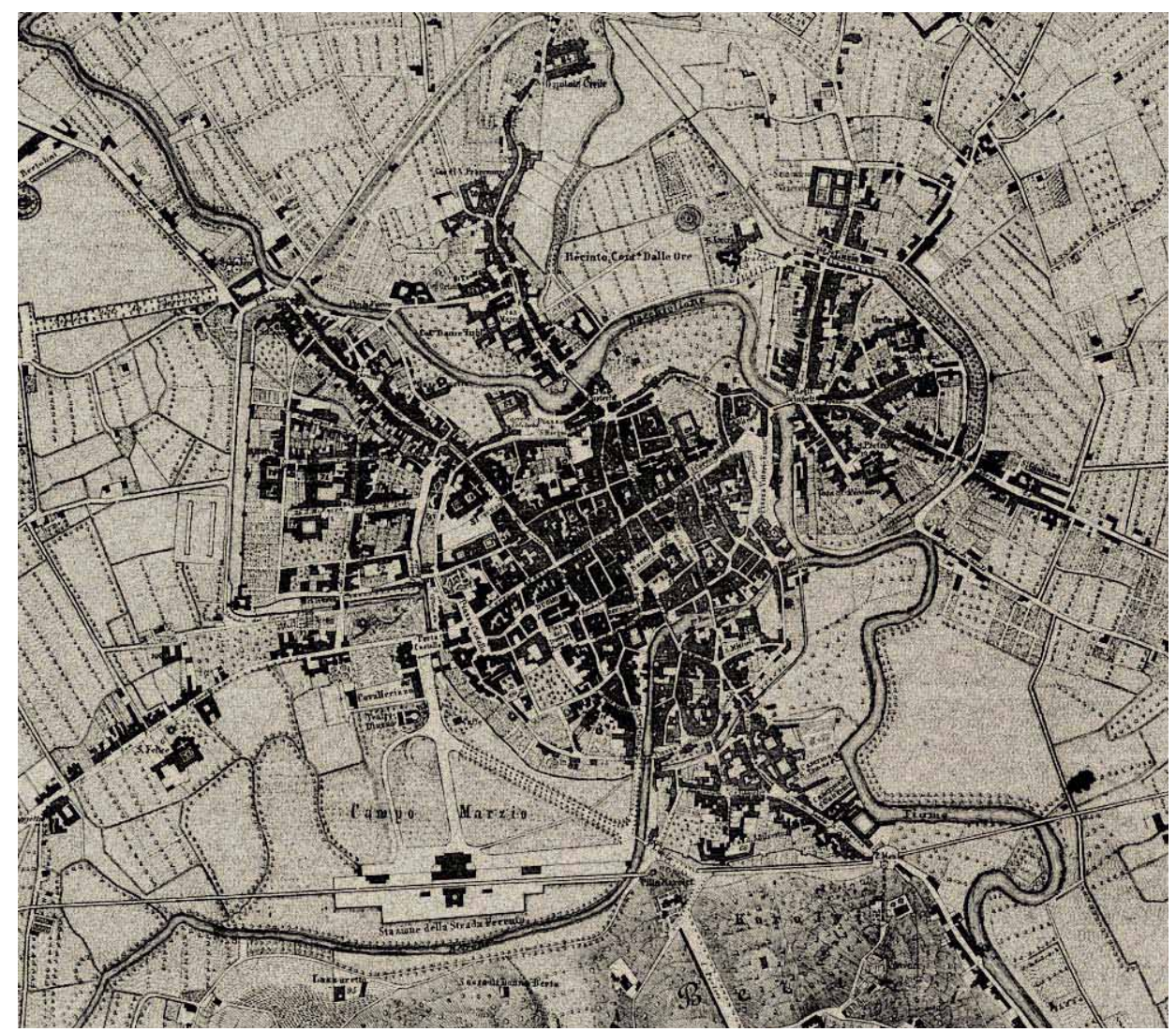

Fig. 2a. Pianta della città di Vicenza (Map of the city of Vicenza), in A. Ciscato, Guida di Vicenza con una carta topografica della città (Guide of Vicenza, with a topographic map of the city), Vicenza, B. Paroni, 1870

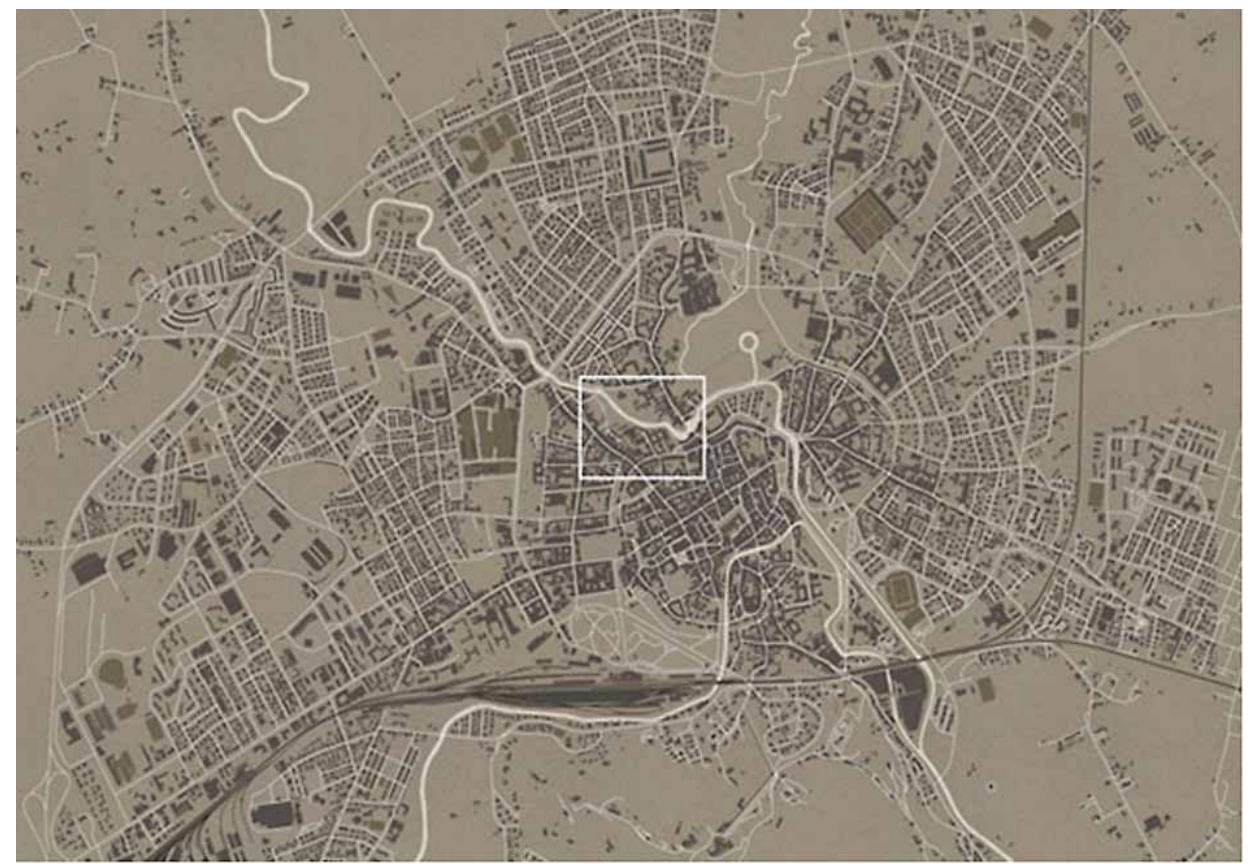

Fig. 2b. Map of Vicenza, showing the position of the study area at the north-west limit of the historic city center (Pozzato 2012) 
city within the walls or even the bridges of St. Paul and St. Michael that cross the Retrone and connect the southern part of the city. The union of these parts, natural aspects and architectural elements, earlier described gives order to the urban form of the city of Vicenza in a general sense. But the architectural element does not end here, because the city of Vicenza is formed by a sequence of public spaces that are connected with one another just as are the different public and private works of the architect Andrea Palladio (1508-1580).

"Two squares in Vicenza, each with its own particular character, are separated by Palladio's Basilica (...). The forms and depths of each square, the way in which the streets flow into, the disposition of the fountains and of the monuments contrast with the characteristics of the adjacent one; but each of these features appears veiled and almost hidden so that it has to be discovered, and the spectator notices only the allure of the entire scene without realizing the cause of so much beauty" (Sitte 1953).

That is how Camillo Sitte expresses his perception of Vicenza's public space. Two squares, Piazza dei Signori (the Lords' Square) and Piazza delle Erbe (the Greengrocers' Square), side by side, separated exclusively by Palladio's most important work, the Basilica, form the heart of the historic center. The center is structured on the Corso Palladio and Corso Fogazzaro streets; the former connects the urban tissue to the Piazza dei Signori and the latter to the Piazza del Duomo (Square of the Cathedral). These two axes offer confortable pathways to people living in the city.

The neoclassic architecture of Andrea Palladio confers to Vicenza a different and particular character, a distinguished personality due to the monumental aspect deriving from its harmonic proportions and mathematical concepts of geometry. This architecture becomes in turn decisive for the city's principal public spaces that are not just those defined by public urban spaces but also include that one developed inside the Basilica itself.

The urban form of the city is articulated by the natural and artificial pathways that connect the different squares and the architecture of Palladio. These flows make Vicenza a city with specific components that give it a different image and provide livable spaces for passers-by, tourists, and residents who walking find a human perception of the architecture and thus of the city.

\section{The case study as a didactic experience}

The place that we are concretely analyzing is an abandoned area of the historic center; in this specific case the area is made up of a wide surface including a zone between the city's walls, the right bank of the Bacchiglione river and an abandoned monastery, later prison, that nevertheless still boasts a monumental exterior (Figs 2b, 3a, 3b, 3c). The projects described below were developed during the Architectural and Urban Composition 2 course (Department of Civil, Environmental and Architectural Engineering of the University of Padua, Italy - chair Enrico Pietrogrande, coworkers Alessandro Dalla Caneva, Ignasi Navàs Salvadò).

Just as many centers of the Veneto Region, Vicenza can trace its foundation to a combination of features: a propitious geographic profile, the river and the Berici hills, and a Roman orthogonal layout. The growth and stratification of the historic center took place in stages and was limited until the last century by the boundary of the city walls. Development was linked to substitution or saturation processes.

The question of urban regeneration of the study area, on the boundary between physical and social degradation, has long been the object of discussion on the part of the local authorities. Once intimately linked to the city's historic center, that area underwent a series of physical transformations leading progressively to a state of degradation. More specifically, the area was paved, used as a parking lot and partially employed to host municipal warehouses. The demolition of the warehouses following a flood which struck the city of Vicenza in November 2010 and the decision to restore the convent of St. Biagio reopened the discussion about urban roles and possible scenarios that the disused area offered to the city.

The desire to re-appropriate free space and the realization that there is no relationship between water and river in other place of the city, all this identifies an opportunity in the long edge of the area to find a relationship between earth and water. City officials are presently planning on pursuing a qualitative restoration of an area that will be used as a public space at the service of its citizens and cultural events.

The project has to be part of the dialectic of the historical process in which preserving and building are components of the same act of consciousness. It will be thus passed the irremediable antagonism between conservatives and innovators because the restore has to be understood in the sense of a re-enactment of the past and the building activity as a continuation of the historical process. In this regard Ernesto Nathan Rogers explains: "Many, who think to be innovators, have in common with so-called conservatives the wrong that both have deep-rooted prejudices, thinking that new and old are in opposition instead of representing the dialectic continuity of the historical process. One and 


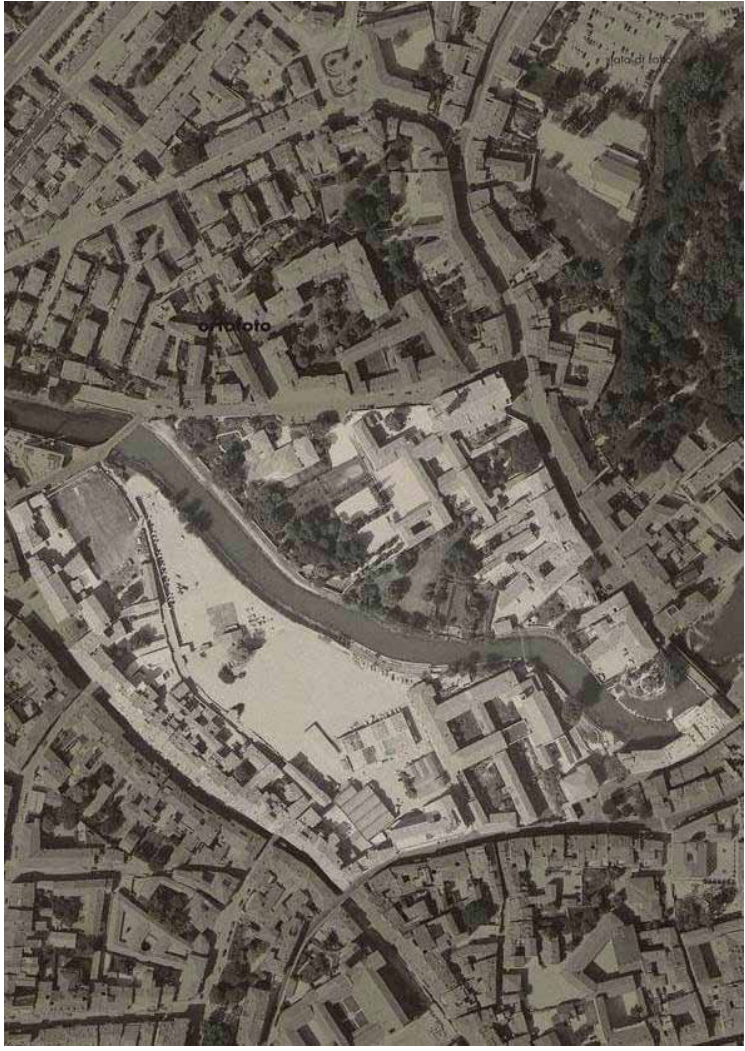

Fig. 3a. The case study area in the historic centre of Vicenza (Pozzato 2012)

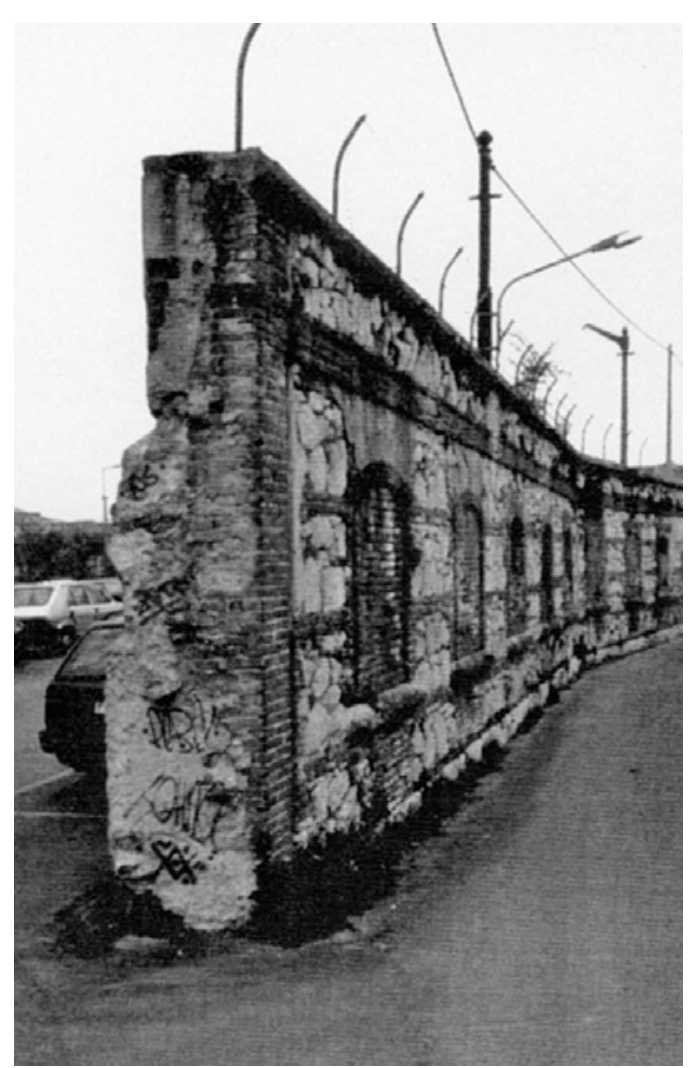

Fig. 3b. View of the city walls (Pozzato 2012)

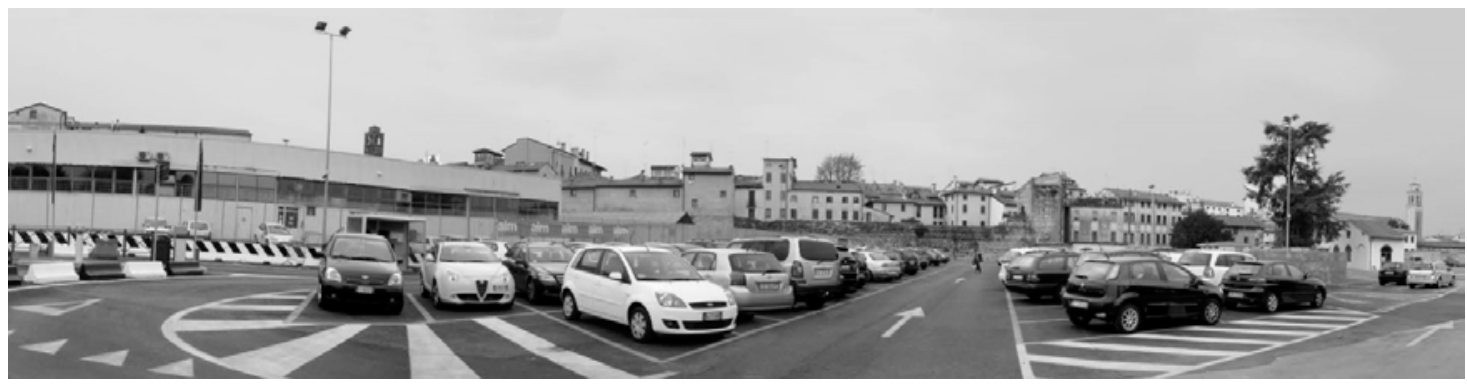

Fig. 3c. View of the case study area, current state (Pozzato 2012)

the other don't go beyond the veneration for certain fruitless appearances. They are not able to penetrate the essences of the styles, pregnant with inexhaustible energy. To try to a priori build in a modern style it is equally absurd to impose respect for the taboo of past styles" (Rogers 1997).

The discussions about requalifying the case study area bathed by the Bacchiglione followed, at the beginning, two lines of thought. The first proposed restoring it as a wide and precious public green space. Favoring the theory of "as it was, where it was", some proposed organizing the space as a large urban park that could be equipped with temporary installations. The second approach, on the contrary, rejected the idea of conserving tout court a situation of the past and considered the needs of a contemporary city as an important factor to create new settlements with new features and destinations.

The idea of a functional and spatial restoration of the area in the light of new needs on the part of the collectivity and respectful of its environmental conditions was the position that ever larger numbers embraced. Consequently, it appears nowadays important to avoid musealising the area and its environmental character in order to reinstate it in light of its social significance and to reintroduce it into the city's vital contemporary circuit.

Focusing on the proposals made by our students, we observe that the project developed by Lucia Pozzato (Fig. 4) aims to safeguard the area's natural character 


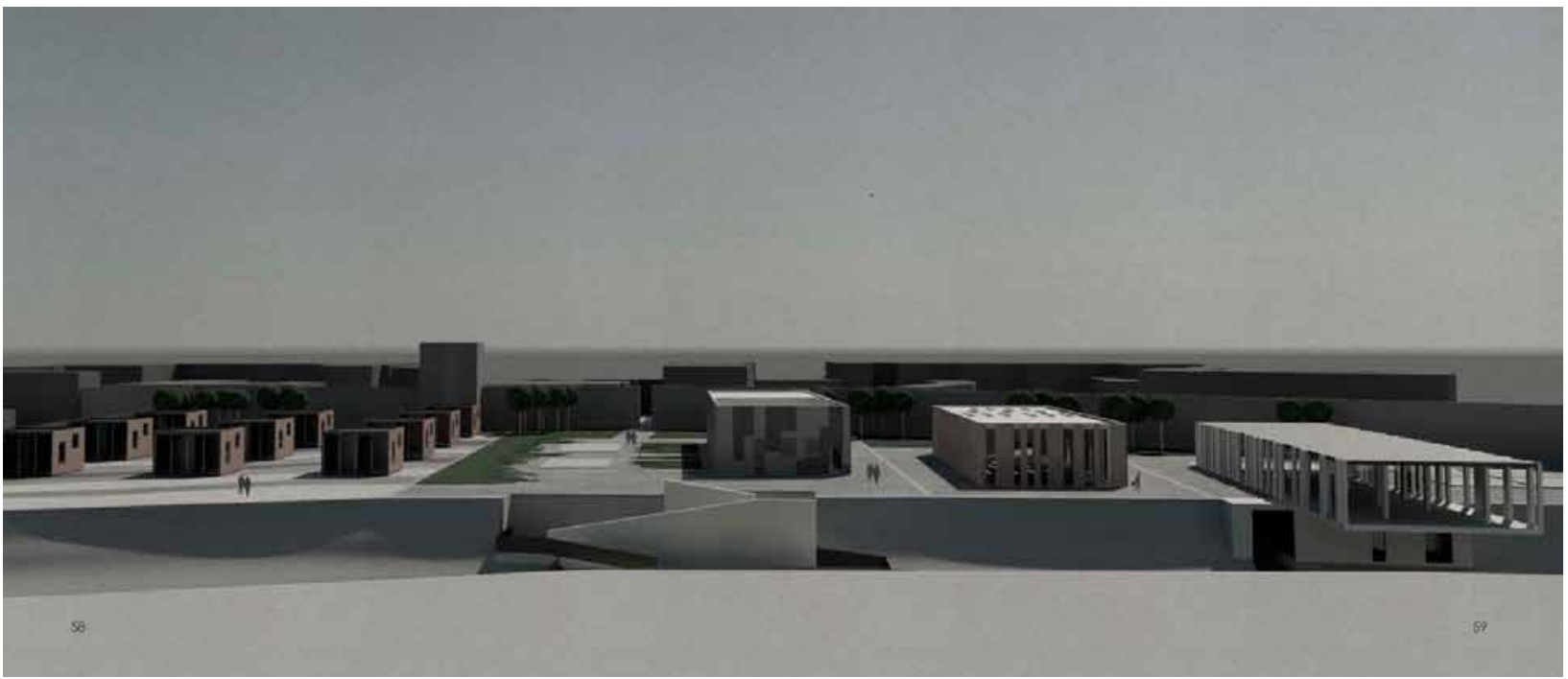

Fig. 4. View from the other side of the river of the study area (Pazzato 2012)

while simultaneously integrating buildings which will allow for the practice of water sports. The new facilities favour swimming and canoeing. The three main constructions are placed radially, like jetties, by the river's curved banks. One structure extends over the river, sheltering vessels and allowing them to navigate the Bacchiglione River. The new structures will reinforce the relationship between the city walls and the river. With the introduction of the water sports facilities in a green area replacing the asphalt surface of the carpark, a historical and natural reference is made to the city's defences of stone and water.

"Mens sana in corpore sano" (a healthy mind in a healthy body) could be the motto accompanying the project carried out by Caterina Bellotto and Giovanni Bronca (Figs 5a, 5b, 5c). Their idea conforms to that of the administrators who favor transforming the parking lot into a green area: a sort of urban park bound on one side by what remains of the ancient city walls and, on the other, by the Bacchiglione river. This project includes the plan for a medical rehabilitation center in a place where natural beauty would serve as an integral part of a reeducation process associated to psychic and physical wellbeing.

The idea of the students becomes part of the park respecting the historical preexistences. The idea already contains the essential characters that will constitute the shape of the architectural project in a consistent manner. The typological reference of the comb-shaped building and of the courtyard volume that are foreseen constitute the founding principle of the project's form. The two bodies, the courtyard and the comb-shaped bodies, are not parallel but rotate around one another in the pursuit of a relation- ship with the boundary of the historic center which is defined by the presence of the ancient walls. The modular, non-aligned grids that constitute the regulating outline for the disposition of the parts are absorbed at the place where they meet at a cylindrical form, reminiscent of the ancient gasometer that was once present at that point, as can be seen in historical plans. The juxtaposition of the parts of the project respects, moreover, the presence of some pre-existing little volumes that the students chose to keep to valorize, in accordance with a thought that was clearly expressed by Rafael Moneo: "History has in any case taught us that the work of architects is always directed towards recognizing and distinguishing what should be eliminated from what deserves to be kept in view of the important role that it played in the context in which it finds itself" (Moneo quoted in Vecci, Tartaglia 2007).

Another important principle of this solution recognized from the very beginning was its horizontal characterization mirroring the horizontal character of the historic center which is located in proximity to the area close to the historic walls. As Le Corbusier taught, choosing the way to build, horizontally rather than vertically, is not a banal choice because it defines the very character of a work. "I design an elongated prism. The other one is cubic. I affirm that the definitive, fundamental architectonic feeling resides in this. Shock is produced. You have affirmed, raising this prism in space with its proportions, this is how I am. You can perceive it even more clearly if the cubic prism is narrowed and raised or if the elongated prism is flattened and stretched. You find characters in front of you, you have created characters. And any- 


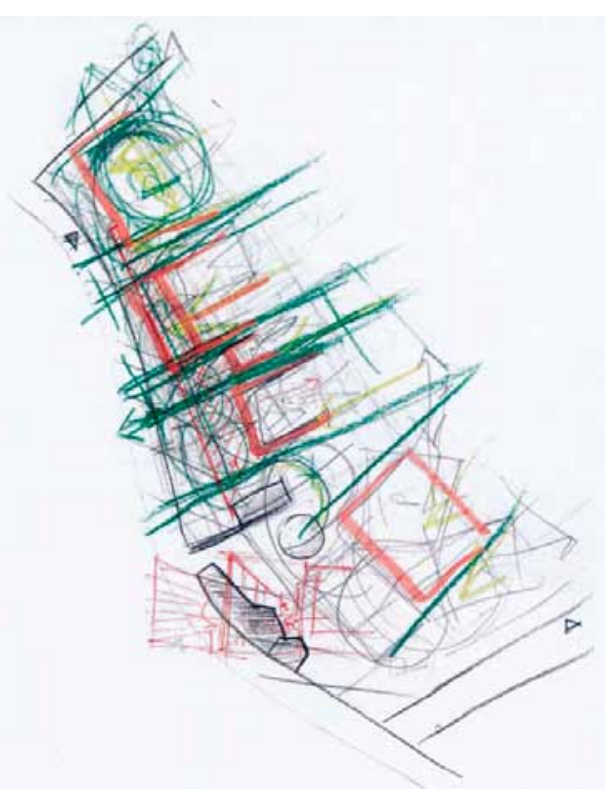

Fig. 5a. Sketch of the project layout (Bellotto, Bronca 2015)

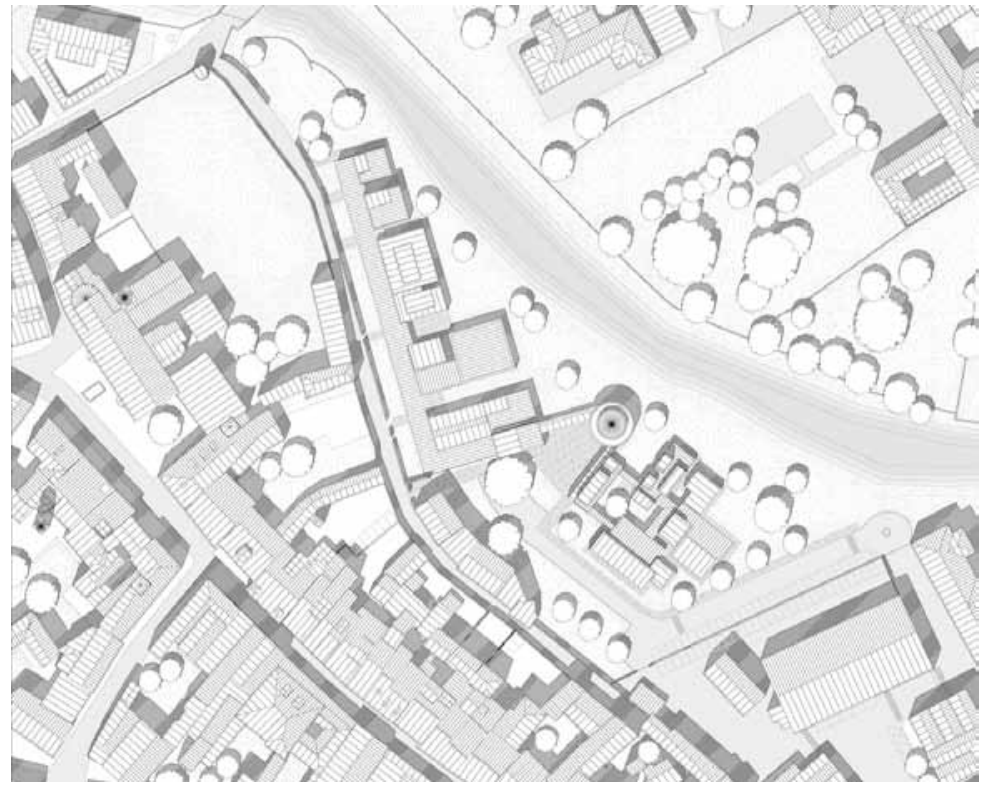

Fig. 5b. Planivolumetric plan

(Bellotto, Bronca 2015) thing you want to add to the work to make it more sophisticated or solid, or more tormented or clear, everything is already determined there, you will not be able to modify the primitive feeling" (Le Corbusier 1929). In accordance with Le Corbusier's thought, the horizontal openness that distinguishes the entire view towards the green space and the Bacchiglione river will not modify the character of the project already deliberately decided from the very beginning by the students.

The wide empty space suggested something quite similar to Alessandra Bardini and Marco Campagnola who treated the area as an urban park where to introduce the volumes of the project (Fig. 6). Their approach is defined by a rigorous modular grid which decisively structures even the green space conditioning the orientation of the pathways. The compositional principle does not refer to the idea of a closed traditional city but rather to the idea of an open city. In fact, it is not so much the close street-building relationship that conditions the project's idea, as in the 19th century city, but the relationship that is established between the building and nature. A principle that the students detected in the works of Le Corbusier when they studied his projects. In both the large scale project of Chandigarth and in the small scale one of Villa Savoye, the fact that the example of the Parthenon and the Campo dei Miracoli in Pisa was used as the compositional principle is clearly evident. With regard to the Parthenon and the buildings of the Acropolis, this is how Le Corbusier expressed his astonishing discovery: "The apparent dis- order of the plan only deceives the layman. The order is not poor. It is determined by the famous landscape that extends from the Piraeus to Mount Pentelicus. The spatial organization is designed to be seen from far. The axes follow the valley and the off-axis are skill by great director" (Le Corbusier 1923).

The functional program whose constituting elements were nonetheless clearly outlined by students doesn't seem as important as the arrangement of volumes within the space. Volumes more than the functions have a longer life or, in synthesis, with the passing of time functions change while forms remain. This is the principle students attempted to follow, according to the consolidated tradition of urban form studies and post-war Italian Rationalism represented by the architect Aldo Rossi. In other words the reference was the idea of a city conceived as a work of art and the form assumed to illustrate its values and not its functions.

\section{Final considerations}

The unresolved condition of the study area, shared with places outside the city center, can be faced by developing a good understanding of specific contexts and by using precise working hypotheses starting with the knowledge of a wider framework of the unified complex represented by the historic city and the spines composing the urban structure.

Planimetric representations highlights the close relationship that the area has with the preexisting natural environment. The link with the formal structure 


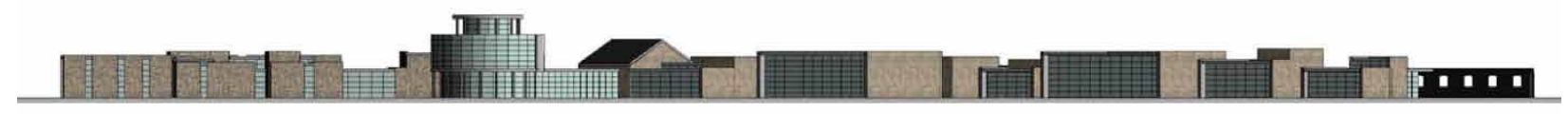

Fig. 5c. The new buildings between the walls of the city and the Bacchiglione river bank. Front on the river (Bellotto, Bronca 2015)
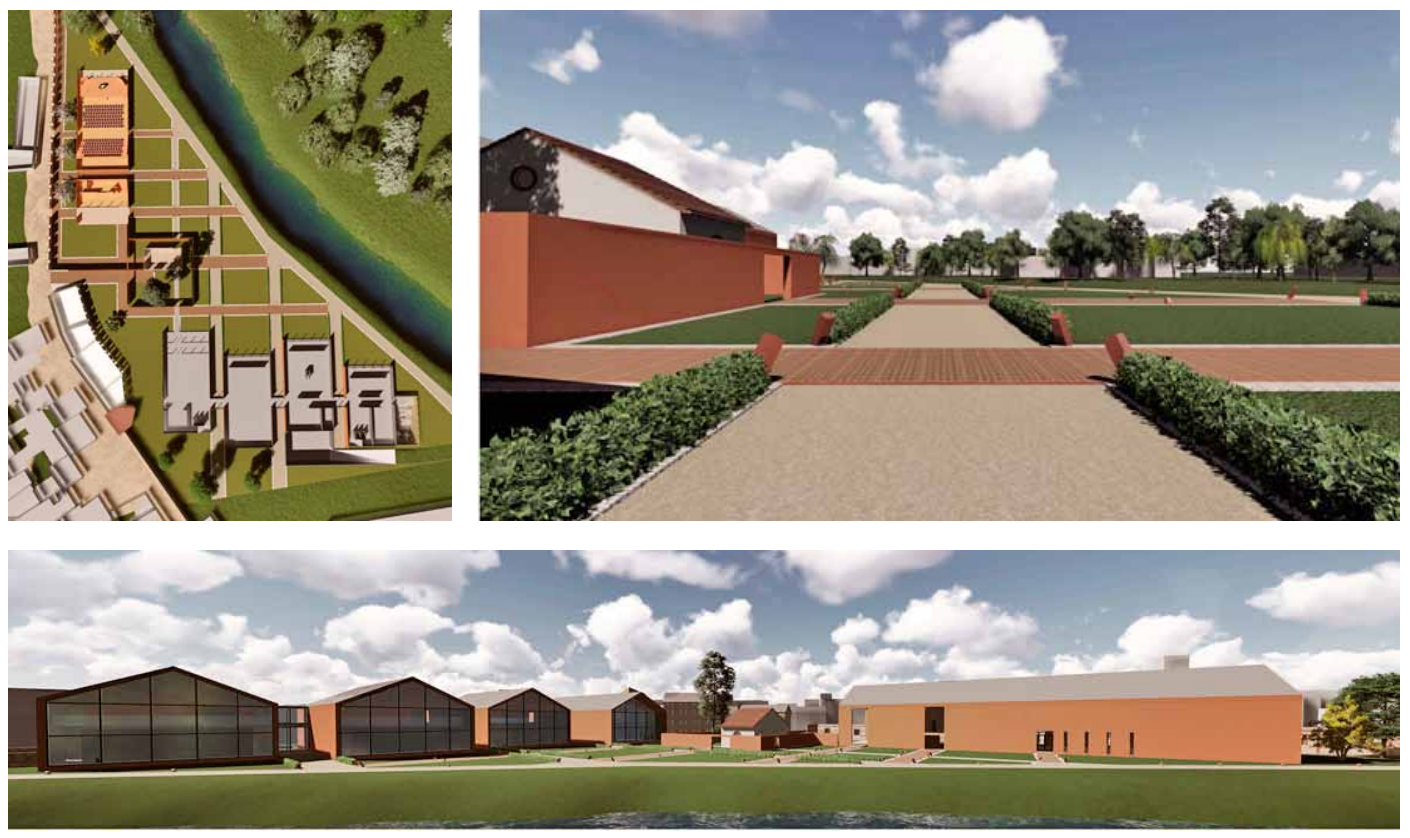

Fig. 6. The urban park proposed by the students Alessandra Bardini and Marco Campagnola. Planivolumetric plan and views of the site (Bardini, Campagnola 2015)

of the historic city as well as the limit defined by the Bacchiglione river are the landscape elements that constitute the necessary premise for a project of urban revitalization and that intends to recuperate its historical, natural and cultural values.

Today the study area can be considered a non-place. The sequence traced by historic events has robbed the city of a unique, naturally beautiful space.

Renewing a dialogue with history by studying the spatial aspects of the transformations as well as those associated with their form is necessary to the formulation of recomposition projects through which visibly new buildings may be made to participate actively in a new unified and coherent structure and layout of the public space.

\section{References}

Baldisseri, C.; Grossi, G.; Minardi, B. 1975. Form of the town, type and architecture, Casabella 401: 20-28.

Bardini A.; Campagnola M. 2015. Vicetia Smart: Design Workshop. University of Padua, Department of Civil, Environmental and Architectural Engineering.
Bellotto, C.; Bronca G. 2015. Fogazzaro: Design Workshop. University of Padua, Department of Civil, Environmental and Architectural Engineering.

Braghieri, G. Introduzione, in G.A. Caleffi, G. Malacarne (Eds.). Progetti veneziani. Milan: Clup, 7.

Calvino, I. 1993. Le città invisibili. Milan: Mondadori, 33.

Caruso, A. 2009. Whatever Happened to Analogue Architecture, AA Files 59: 74-75.

Ciscato, A. 1870. Guida di Vicenza con una carta topografica della città (Guide of Vicenza, with a topographic map of the city). Vicenza: B. Paroni.

Crippa, M. 1964. Vicenza; il Centro Storico nei comprensori territoriali, Bollettino del Centro Internazionale di studi Andrea Palladio 6: 434.

Delledonne, N. 2005. Tipologie e mondi referenziali, AIÓN 9: 143-147.

Domenichini, R. 2011. Il corso di Elementi di architettura, da Del Giudice a Trincanato, in G. Zucconi, M. Carraro (Eds.). Saggi sulla scuola di architettura di Venezia, Venice: Marsilio Editori, 68.

Le Corbusier, 1979 (first edition 1930). Prologo americano, in F. Tentori (Ed.). Precisazioni sullo stato attuale dell'architettura e dell'urbanistica, Rome-Bari: Laterza, 88.

Le Corbusier. 1923. Vers une architecture. Paris: Cres \& C., 39. 
Martí Arís, C. 1994. Le variazioni dell'identità. Il tipo in architettura. Milan: CittàStudi, 167.

Moneo, R. 2012. L'altra modernità. Considerazioni sul futuro dell'architettura, Milan: Christian Marinotti Edizioni.

Monestiroli, A. 2010. La forma rispondente. Bologna: Ogni uomo è tutti gli uomini Edizioni, 20.

Pietrogrande, E.; Rabacchin, A.; Dalla Caneva, A. 2014. Plans for the historic centre of Padua, Italy Issues with urban morphology. Officina, Rome.

Polesello, G. 2002. Ab initio, indagatio initiorum. Ricordi e confessioni, in Posocco, P.; Radicchio, G.; Rakowitz, G. (Eds.). Care architetture. Turin: Umberto Allemandi and C., 17-18.

Pozzato, L. 2012. San Biagio e contrà Mure Carmini, Vicenza. Nuovo approccio al fiume: Master's thesis. University of Padua, Department of Civil, Environmental and Architectural Engineering.

Rogers, E. N. 1997 (first edition 1958). Esperienza dell'architettura. Milan: Ginevra, 279.

Rossi, A. 1966. L'architettura della città. Padua: Marsilio Editori.

Rossi, A. 1970. Caratteri urbani delle città venete, in La città di Padova. Saggio di analisi urbana. Officina, Rome, 421, $434,477$.

Samonà, G. 1929. Tradizionalismo ed internazionalismo architettonico, Rassegna di Architettura 12: 466.

Semerani, L. 1982. La scuola di Venezia, in Progetti per la città veneta 1926-1981. Vicenza: Neri Pozza Editore, 17.

Sitte, C. 1953. L'arte di costruire le città: l'urbanistica secondo $i$ suoi fondamenti artistici. Milan: Antonio Vallardi Editore.

Vecci, T.; Tartaglia, A. 2007. Saper credere in architettura. Venti domande a Rafael Moneo. Naples: Clean Edizioni, 32.

Vidler, A. 2005. La terza tipologia, AIÓN 9: 37-42.

\section{ENRICO PIETROGRANDE}

Assistant Professor of Architectural and urban composition at Padua University, Department of Civil, Environmental and Architectural Engineering. Graduated in Civil Engeenering at Padua University (1981) and in Architecture at Iuav in Venice (1989). PhD at Bologna University (2001). He is particularly interested in the relationship between architecture and history in the city. About the theme of new architecture in historic and artistic context published (with Adriano Rabacchin and Alessandro Dalla Caneva) Plans for the historic centre of Padua, Italy. Issues with urban morphology (2014).

\section{ALESSANDRO DALLA CANEVA}

Graduated in Architecture at Iuav in Venice. PhD in Architectural Composition, XXI cycle (Venice, 2009). He published the books Il museo municipale a Den Haag di Hendrik Petrus Berlage (2011), Le scuole di Willem Marinus Dudok ad Hilversum (2014) and Il Teatro dell'opera di Jan Frederik Staal ad Amsterdam 1925-1928. Il luogo e il progetto (2015). He currently works at the Department of Civil Environmental and Architectural Engineering of Padua, course of Architectural and Urban Composition 2.

\section{IGNASI NAVÀS SALVADÓ}

Graduated in Architecture at ETSAB in Barcelona. Master in theory and practice of the architectural project at ETSAB (Barcelona 2014). Assistant Professor of Architectural projects at ETSAB (2011-2014). Professor of Architectural projects at ETSAB (2012-2014) by scholarship of "Generalitat de Catalunya"). Collaborator and researcher at the Department of Civil Environmental and Architectural Engineering of Padua, course of Architectural and Urban Composition 2 (2014). He published, Zumthor, architecture for a place (2012), Siza, architecture of the memory (2014) and The architectural process of the Santa Caterina Market Rehabilitation. An approach in the Enric Miralles Architecture (2014). 